\title{
Hevosalan investoinnit ja yrittäjyyden muutokset 2000-2010
}

\author{
Jukka Korhonen $^{1)}$, Sirpa Pussinen ${ }^{1)}$, Tapani Yrjölä ${ }^{2)}$, Rauni Varkia ${ }^{1)}$ ja Janne Asukas ${ }^{1)}$ \\ ${ }^{1)}$ Laurea-ammattikorkeakoulu, Uudenmaankatu 22, 05800 Hyvinkää, etunimi.sukunimi@laurea.fi \\ 2) Suomen Gallup Elintarviketieto, PL 505, 02101 Espoo, tapani.yrjola@tns-global.com
}

\section{Tiivistelmä}

Hevosala on viime vuosina ollut kasvussa. Hevosten lukumäärä on kasvanut noin tuhannella yksilöllä vuodessa, hevosmäärän ollessa vuonna 2005 noin 70 000. Hevosalalle on tullut uusia harrastajia ja yrittäjiä. Kasvusuunnassa olevalla toimialalla on ollut tarvetta valtakunnalliseen koko toimialaa koskevaan tutkimukseen, jossa tarkastelun kohteena ovat alan kehityssuunta, investoinnit ja yritystoiminta.

Hevosalan investoinnit ja yrittäjyyden muutokset -tutkimuksessa on tarkastelun kohteena TEkeskusalueittain alan investoinnit ja yritystoiminta ajanjaksolla 2000-2010. Tutkimusaineistona olevan kyselyn on toteuttanut Suomen Gallup Elintarviketieto Oy. Muilta osin tutkimuksen toteuttaa Laureaammattikorkeakoulu vuosien 2005-2006 aikana. Kyselyn tilaajana on ollut hevosalan järjestöjen ja toimijoiden kanssa yhteistyössä toteutunut Hevosalan yrittäjyyden kehittämishanke (2004-2005), joka on saanut rahoitusta Uudenmaan TE-keskuksen kautta ALMA-ohjelmasta, jonka rahoituslähteenä on Euroopan maatalouden ohjaus- ja tukirahasto (EMOTR).

Suomen Gallup Elintarviketieto toteutti valtakunnallisen kyselytutkimuksen keväällä 2005. Puhelinhaastatteluna tehtyyn kyselyyn vastasi 1172 vähintään kolmen hevosen omistajaa. Hevosalan investoinnit ja yrittäjyyden muutokset -kyselyn vastaajajoukko kattaa noin 30 \% vähintään kolmen hevosen omistajista. Hevostoimintaa yritystoimintana harjoittaa $40 \%$ ja harrastusmuotoisena $60 \%$ vastaajista. Kyselyn mukaan kiinnostusta yritystoiminnan aloittamiseen ja laajentamiseen on tasaisesti koko maassa. Hevostaloutta harrastavista $27 \%$ on aikeissa todennäköisesti tai mahdollisesti aloittaa yritystoiminnan vuoteen 2010 mennessä. Tämä merkitsee toteutuessaan 1300 hevosalan yrityksen syntymistä. Puolet nykyisistä yrityksistä aikoo laajentaa toimintaa seuraavien viiden vuoden aikana. Vastauksista käy ilmi, että hevosalalla on investoitu aktiivisesti toimintaympäristöön ja hevosiin. Tallitoimintaa harjoittavista vastaajista $70 \%$ on investoinut rakennuksiin tai olosuhteisiin vuosien 2000-2005 aikana. Eniten on investoitu hevosten ulkoiluja harjoittelualueisiin, vanhojen tallien peruskorjaukseen, uusien tallien rakentamiseen ja lantalainvestointeihin. Myös lähitulevaisuudessa investoidaan: toimintaympäristöön tai hevosiin kohdistuvia hankintoja suunnittelee 56 \% vastaajista. Talliyksiköiden kasvu on kuitenkin maltillista, sillä vuonna 2005 keskimäärin tallissa on 18 hevospaikkaa viiden vuoden kuluttua sen ollessa 19 paikkaa. Hevosalan kasvu aiheuttaa kehittämistarpeita tiedonsiirtoon ja osaamiseen turvaamiseen. Vastaajista $70 \%$ on osallistunut koulutus- ja infotilaisuuksiin, käyttänyt tallikohtaista neuvontaa tai asiantuntija-apua. Neuvonnan tarve korostuu erityisesti yritystoiminnan aloittamis- ja laajentamisvaiheessa. Hevosalan kilpailukyky vahvistuu osaamista lisäämällä. Yritysten parantuneesta kilpailukyvystä hyötyvät viime kädessä palvelujen käyttäjät.

Asiasanat: Maaseutuyrittäjyys, hevostalous, investoinnit 


\section{Johdanto}

Hevosala on ollut viime vuosina ollut voimakkaassa kasvussa. Hevosharrastuksen ja yritystoiminnan lisääntyessä on syntynyt uusia talleja ja yrityksiä, jotka ovat investoineet aktiivisesti. Hevosten määrä on kaksinkertaistunut vuodesta 1980, kun vuonna 2004 rekisterissä olevien hevosten lukumäärä oli 61000 hevosta (Suomen Hippos ry, tilastot). Kun mukaan luetaan rekisteröimättömät hevoset, arvioidaan koko maassa olevan yhteensä noin 70000 hevosta. Hevosen rooli on ajan kuluessa muuttunut työkäytöstä urheilu- ja harrastushevoseksi. Hevosalan palvelutarjonta on näin ollen monipuolistunut viimeisten vuosikymmenten aikana.

Hevosalan investoinnit ja yrittäjyyden muutokset -tutkimuksen tavoitteena on selvittää hevosalan valtakunnallista kehitystä vuosina 2000 - 2010. Tutkimuskohteena ovat hevosalalle kohdistuneet a) yritystoiminnan muutokset ja kiinnostus toiminnan aloittamiseen sekä b) investoinnit toimintaympäristöön ja hevosiin. Tässä yhteydessä tulosten tarkastelu on painottunut toimintaympäristön investointeihin, ei hevosiin kohdistuviin hankintoihin. Tarkoituksena on selvittää, onko toimialana uusi hevosala edelleen kasvussa ja millaisia muutoksia yritystoimintaan on odotettavissa lähitulevaisuudessa. Analysointia on tehty TEkeskusalueittain, jotta tietojen hyödyntäminen olisi mahdollisimman laajaa myös alue- ja yritystasolla. Tulokset viestivät hevosalan kehityssuuntaa ja kehittämistarpeita niin hevosalan sisälle kuin sidosryhmille.

\section{Aineisto ja menetelmät}

Hevosalan investoinnit ja yrittäjyyden muutokset -tutkimuksen toteuttajana on Laureaammattikorkeakoulu. Suunnittelu on tehty yhteistyössä hevosalan järjestöjen ja toimijoiden kanssa. Tutkimukseen liittyvän kyselyn on toteuttanut Suomen Gallup Elintarviketieto Oy, Laureaammattikorkeakoulun Hevosalan yrittäjyyden kehittämishankkeen (2004-2005) tilauksesta. Hevosalan yrittäjyyden kehittämishankkeelle on myönnetty rahoitusta Uudenmaan TE-keskuksen kautta alueellisesta maaseutuohjelmasta ALMA:sta, jonka rahoituslähteenä on Euroopan maatalouden ohjaus- ja tukirahasto (EMOTR). Kyselyn tulosten julkistaminen toteutuu kahdessa osassa: keskeisistä tuloksista on koottu yhteenveto syksyllä 2005. Kyselyaineiston analysointia ja tutkimustyötä jatketaan Laureaammattikorkeakoulussa vuoden 2006 aikana.

Hevosalan investoinnit ja yrittäjyyden muutokset -kysely on toteutettu valtakunnallisesti keväällä 2005. Puhelinhaastatteluna tehtyyn kyselyyn vastasi 1172 yli kolmen hevosen omistajaa. Osoitetietojen lähteenä on käytetty Suomen Hippos ry:n hevosenomistajarekisteriä ja Suomen Ratsastajainliiton osoiterekisteriä. Alueellista tarkastelua on painotettu TE-keskusalueiden (15 kpl) mukaisesti. Kyselyn vastaajajoukko, 1 172, kattaa noin 30 \% yli kolmen hevosen omistajista ja edustaa 8 \% kaikista hevostalleista. Vastaajajoukossa on sekä ravihevosten (yli 50 \%) että ratsuhevosten (40 \%) omistajia. Kyselyn otannassa on huomioitu eri alueiden hevosmäärät ja kyselyjä on painotettu sen mukaisesti. Esimerkiksi Uudellamaalla, jossa on hevosia ja hevosenomistajia on paljon, on vastausmäärä 134 ja vastaavasti Kainuussa, jossa hevosmäärä on vähäinen, on vastauksia koottu 27. Suomen Hippoksen omistajarekisterissä yli kolmen hevosen omistajia on yhteensä 3555. Otantaa rajattiin omistajatietojen oikeellisuuden varmistamiseksi rajauksella 'omistuksessa vähintään yksi nuori hevonen' (synt. 1998-2004), jolloin koko joukko oli 3000. Kaikkiaan hevosenomistajia arvioidaan olevan koko maassa 35 000. Päätoimisia hoito- ja valmennuspalveluja tarjoavia talleja on rajauksesta johtuen pudonnut pois, koska tallipaikkoja vuokraavat yrittäjät eivät välttämättä omista kolmea hevosta.

\section{Tulokset ja tulosten tarkastelu}

Tutkimuksen tulosten tarkastelussa ovat a) hevosalan yritystoiminnan ja toimintamuotojen muutokset sekä b) toteutuneet ja suunnitteilla olevat investoinnit.

Kyselyyn vastanneista 1172 hevosenomistajasta harjoittaa toimintaa $40 \%$ yritystoimintana ja $60 \%$ harrastusmuotoisena. Vastaajista $5 \%$ ovat hevosenomistajia, joilla ei ole tallitoimintaa. Vastaajista $30 \%$ on alle 40-vuotiaita, $25 \%$ 40-49 -vuotiaita, $26 \%$ 50-59 -vuotiaita ja $18 \%$ yli 60 -vuotiaita. Tallitoiminta on usein aloitettu verrattain hiljattain, sillä $30 \%$ on aloittanut tallitoiminnan 2000-luvulla. Suurimmalla osalla talleista toiminta koostuu useista eri toiminnoista. Pääasialliset toimintamuodot, sekä harrastus- että yritystalleilla, ovat tällä hetkellä hevoskasvatus omaan käyttöön tai myyntiin (kaikista kyselyyn vastanneista $33 \%)$, omien tai vieraiden hevosten ravivalmennus (30 \%) ja ratsastustunnit (13\%). Päätoimintamuodoksi oman harrastuskäytön ilmoitti 13 \% vastaajista. Pääasiallisen toiminnan lisäksi muuta toimintaa ovat yleisimmin karsinapaikkojen vuokraus (27 \%) ja vaellusratsastus- ja matkailupalvelut (7 \%). 
Tallien pääasiallinen toiminta ja hevosten käyttötarkoitus vaihtelee alueittain (kuva 1). EteläSuomen alueella on eniten ratsuhevosia kun taas Pohjanmaan, Itä- ja Pohjois-Suomen alueella painopiste on ravihevosiin liittyvässä toiminnassa. Kyselyn mukaan päätoimintamuodot säilyvät lähitulevaisuudessa samankaltaisena, mutta palvelutoiminta, kuten hevosmatkailu- ja elämyspalvelut, ovat kasvava osa hevosalan yrittäjyyttä. Kyselyn mukaan majoitus-, kokous- ja ruokailutilojen investointeihin aiotaan panostaa erityisesti Lapin ja Kainuun alueen yrityksissä, jossa hevosmatkailulla on merkittävä rooli. Mahdollisuuksia on edelleen hevosen käytössä osana terveydenhuolto- ja sosiaalialan palveluja, esim. terapiaratsastuksessa.

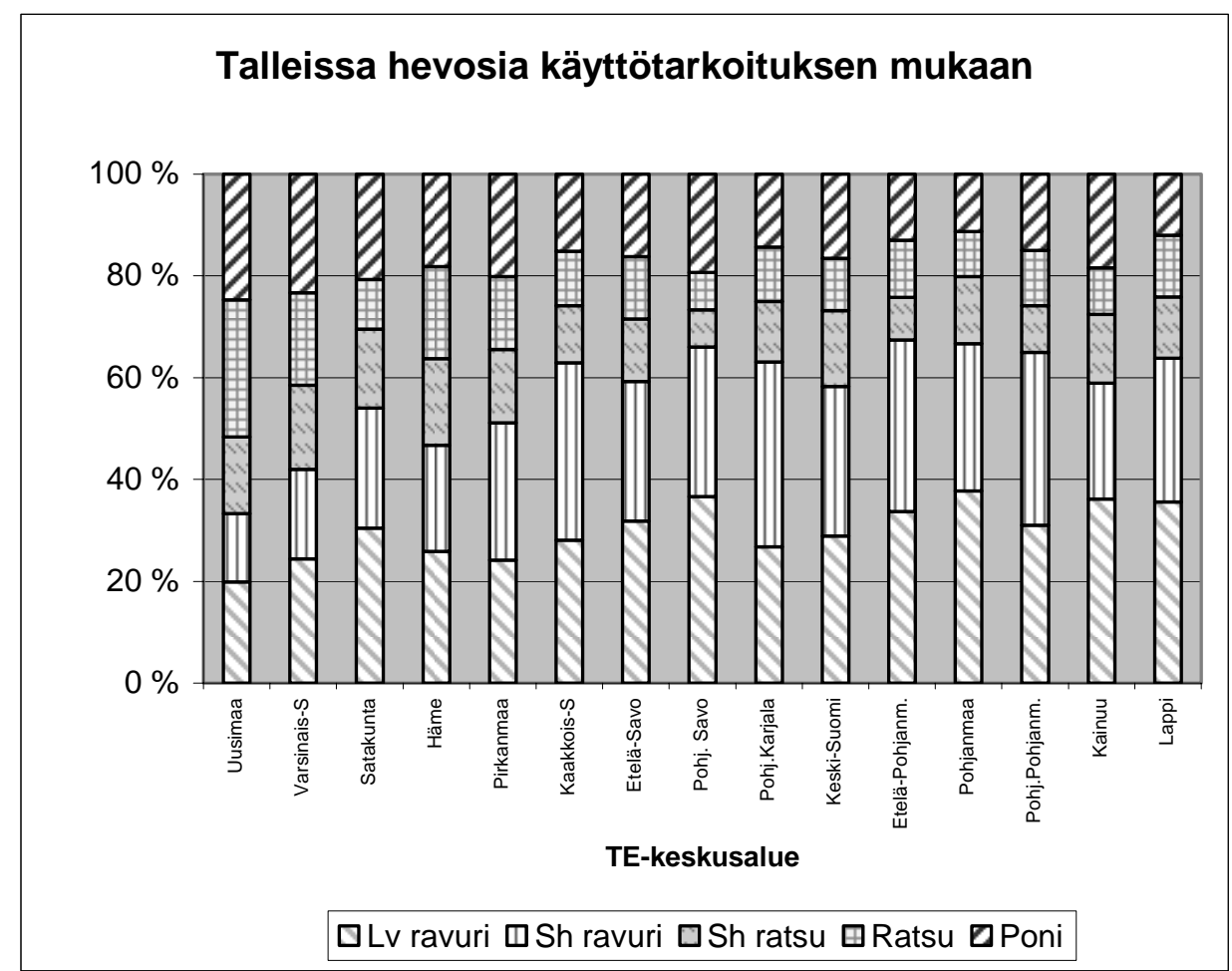

Kuva 1. Hevosten käyttötarkoitus alueittain.

Hevosyritysten liikevaihto vaihtelee alueittain ja toimintamuodoittain (kuva 2). Hevosyritysten keskimääräinen liikevaihto oli 68000 euroa/ vuosi. Liikevaihdoltaan Etelä-Suomen hevosyritykset ovat muuta maata mittavampia. Esimerkiksi Uudenmaan ja Varsinais-Suomen TE-keskuksen alueella liikevaihdot olivat keskimäärin 142000 euroa ja 110000 euroa, kun taas Pohjois-Suomessa liikevaihto liikkuu 30000 - 40000 euron välillä. Yrityksistä 6 \%:n liikevaihto ylittää 200000 euroa. Hevosyrityksiä verotetaan elinkeinoverolain (EVL) tai maatilatalouden tuloverolain (MVL) mukaisesti. Kyselyn yrityksistä EVL:n piirissä on 40 \% ja MVL:n mukaan verotetaan $60 \%$. 


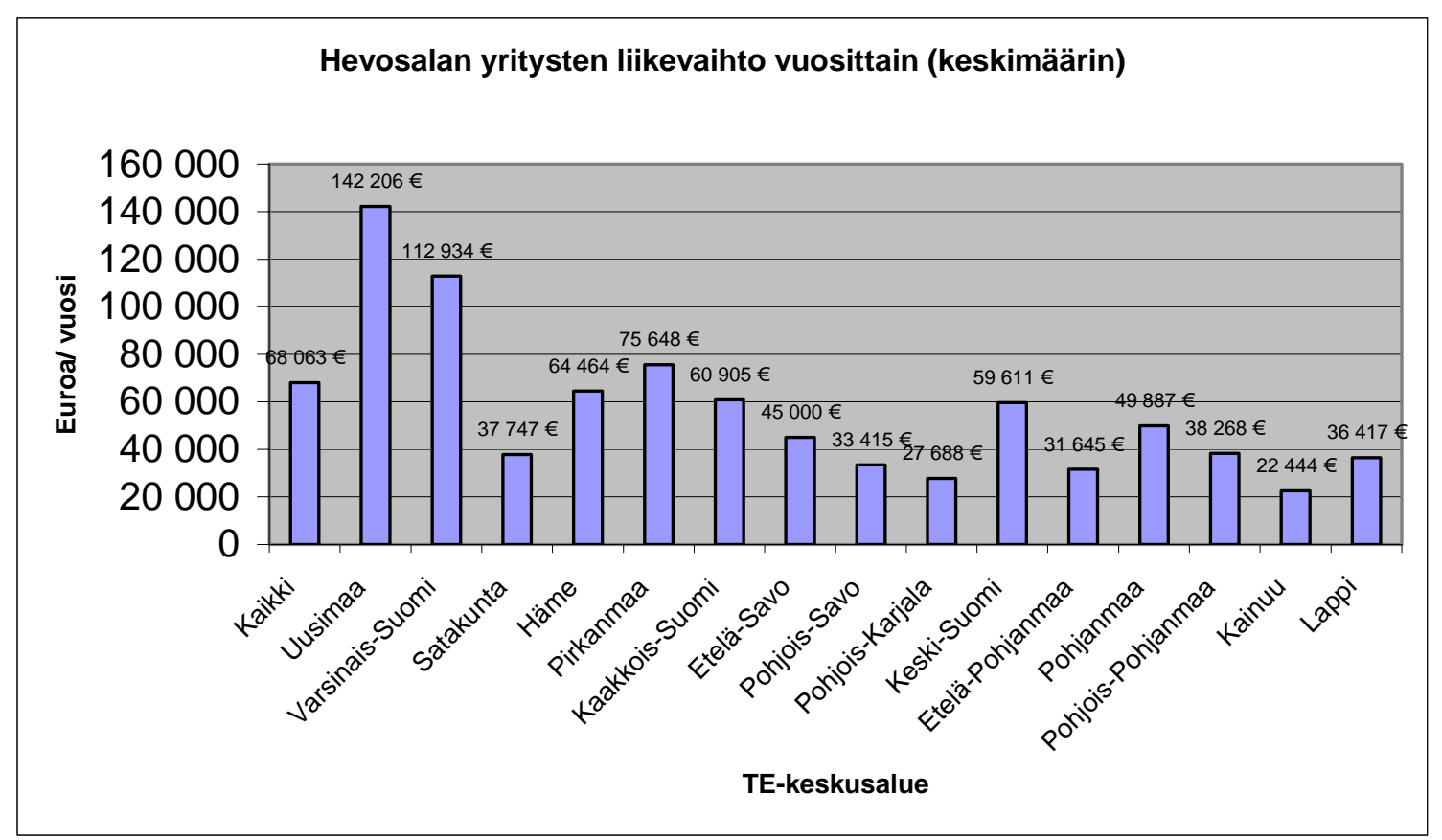

Kuva 2 Hevosyritysten liikevaihto alueittain.

Kiinnostusta yritystoiminnan aloittamiseen ja laajentamiseen on tasaisesti koko maassa (kuva 3). Kyselyyn vastanneista (joilla ei ole yritystoimintaa) $27 \%$ on aikeissa todennäköisesti tai mahdollisesti aloittaa yritystoimintaa seuraavan viiden vuoden aikana. Kiinnostus vaihtelee alueittain. Uusia yrityksiä on syntymässä erityisesti Etelä-Suomeen. Yritystoimintaa harjoittavilla talleilla suuntana on toiminnan laajentaminen (48 \%) tai säilyttäminen ennallaan (41 \%). Toisaalta yrityksissä, jotka ovat viime vuosien aikana investoineet, keskitytään kehittämään toimintaa investointien tasolle ja ottamaan tehdyt investoinnit täysipainoisesti käyttöön.

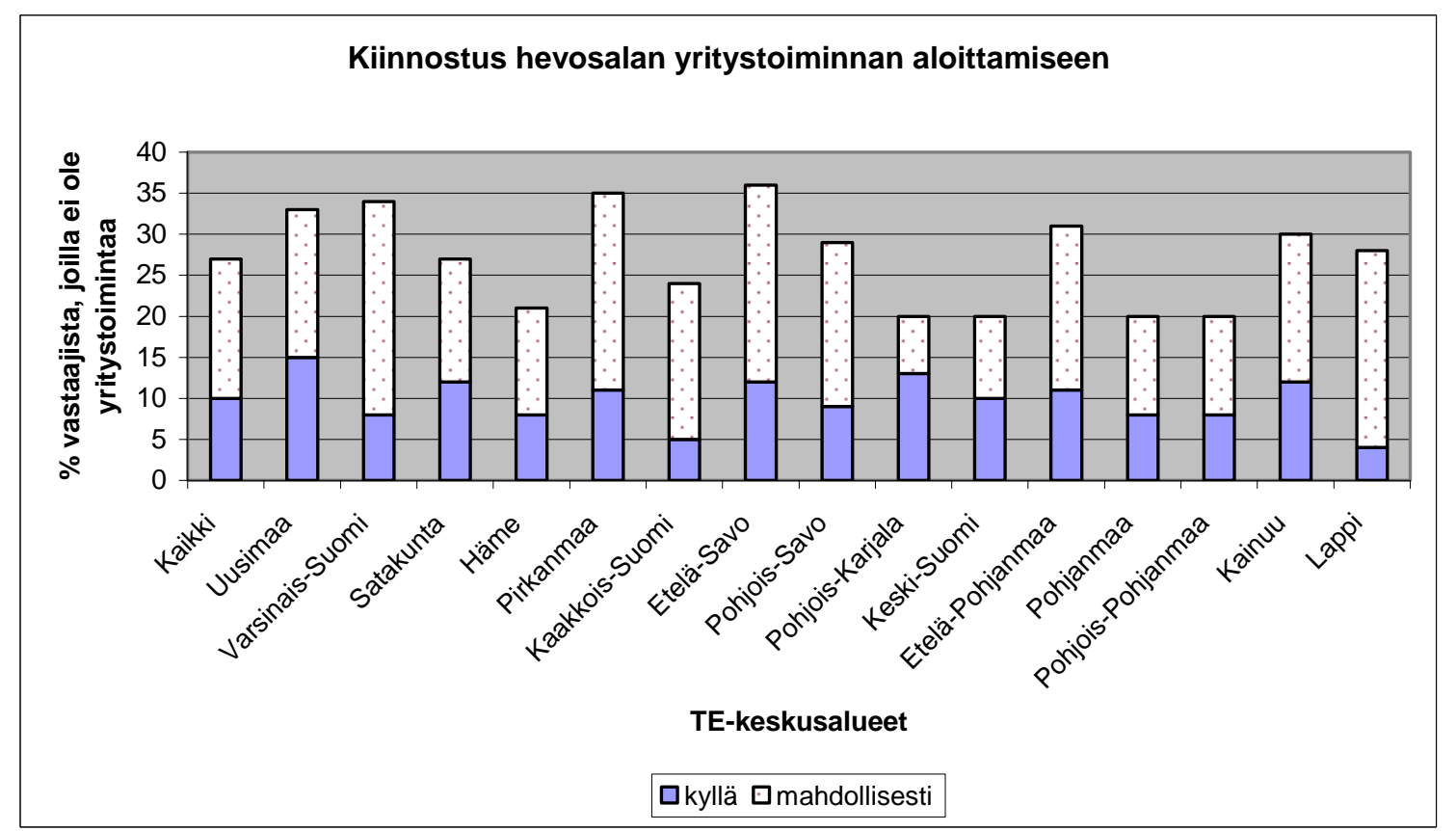

Kuva 3 Hevosyrittäjyyden kiinnostavuus alueittain 
Hevosalalla investoidaan voimakkaasti toimintaympäristöön ja hevosiin. Tallitoimintaa harjoittavista vastaajista $70 \%$ on investoinut rakennuksiin tai olosuhteisiin vuosien 2000-2005 aikana. Eniten on investoitu hevosten ulkoilu- ja harjoittelualueisiin, vanhojen tallien peruskorjaukseen, uusien tallien rakentamiseen ja lantaloihin. Kyselyyn vastanneiden mukaan investointien suuruusluokat ovat olleet keskimäärin: uuden tallin rakentaminen 72000 euroa, lantala 6200 euroa, ulkoilualueet 4200 euroa, harjoittelualueet (reitit, kentät, harjoitusradat) 8500 euroa ja maneesi 147000 euroa. Investointihalukkuutta on edelleen, vaikka huippu onkin ohitettu. Seuraavien viiden vuoden aikana 56 \% vastaajista suunnittelee investointeja hevosiin tai toimintaympäristöön (kuva 4). Rahamääräisesti merkittävimmät investointikohteet ovat uusien tallien ja maneesien rakentaminen. Etelä-Suomen alueella on tehty muuta maata suurempia kertainvestointeja. Talliyksiköiden kasvu on kuitenkin maltillista, sillä vuonna 2005 keskimäärin tallissa on 18 hevospaikkaa viiden vuoden kuluttua sen ollessa 19 paikkaa.

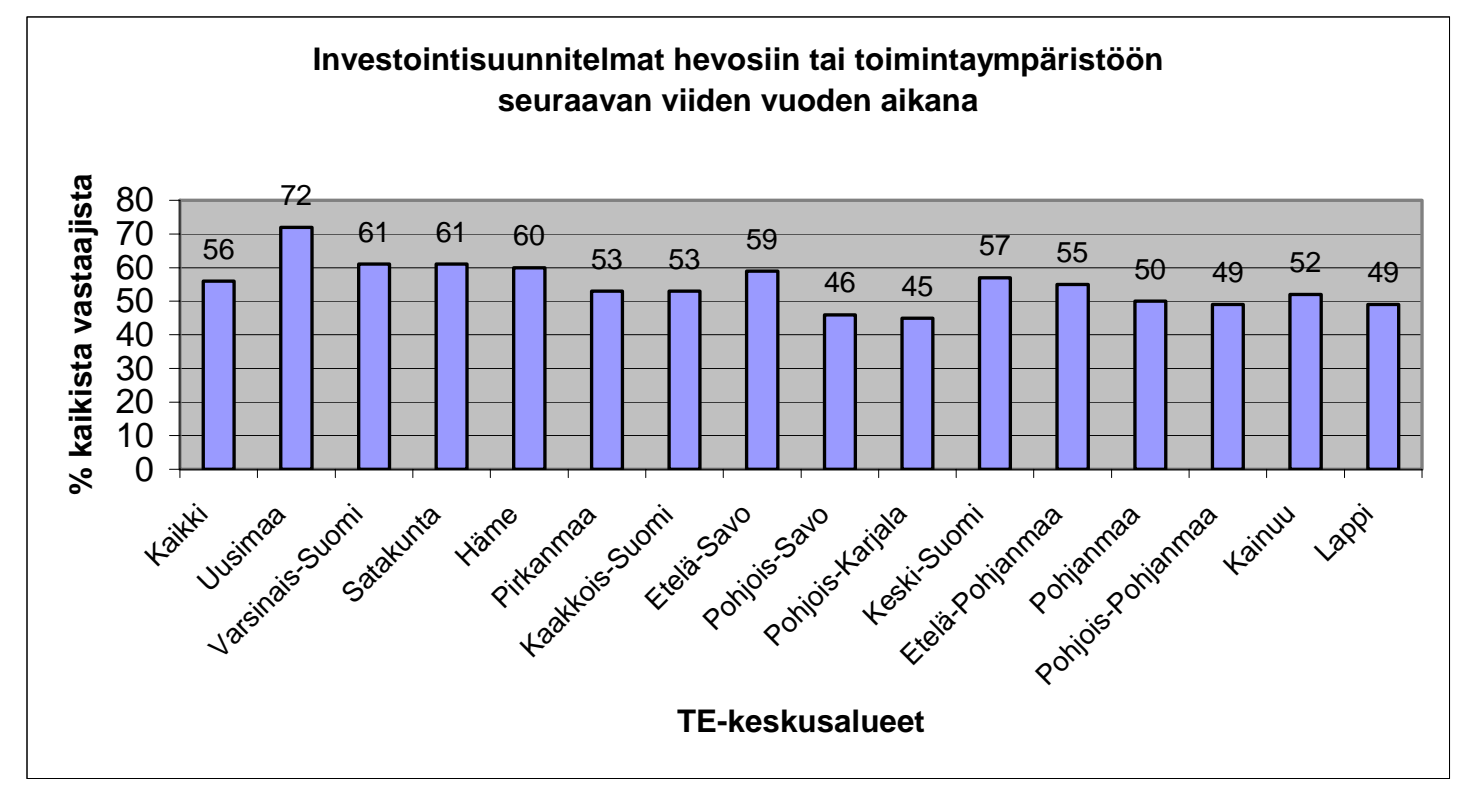

Kuva 4. Hevosyritysten investointiaikomukset alueittain

Yritystoimintaa harjoittavista $38 \%$ on saanut investointiin julkista tukea TE-keskuksesta tai muualta. Tukea on yleisimmin saatu Pohjois- ja Keski-Suomessa, missä investointien kannattavuus riippuu julkisesta tuesta. Erityisesti toiminnan aloittamis- ja laajentamisvaiheessa on tarvetta neuvonnalle ja asiantuntijapalveluille. Vastaajista $70 \%$ on osallistunut koulutus- ja infotilaisuuksiin, käyttänyt tallikohtaista neuvontaa tai asiantuntija-apua. Neuvonta ja koulutuspalveluita aikoo vastaajista 59 \% käyttää myös jatkossa. Neuvonta kohdistuu erityisesti hevosten hoitoon ja jalostukseen (71\%), rakennusneuvontaan (31 \%), yritysja talousneuvontaan (27\%) sekä ympäristöasioihin (26 \%). 


\section{Johtopäätökset}

Hevosalan investoinnit ja yrittäjyyden muutokset -tutkimus osoittaa toimialan kehityssuuntaa eri toimintamuodoissa TE-keskusalueittain. Tutkimuksen perusteella voidaan arvioida hevosalan kehitystä vähintään kolmen hevosen omistajien joukossa. Tavoittamattomissa on lukuisa harrastajien joukko, joka suunnittelee talli- tai yritystoiminnan aloittamista lähitulevaisuudessa. Tutkimustulokset vahvistavat hevosalan vaikuttavuutta ja yhteiskunnallista merkittävyyttä yhtenä pienyrittäjyyden muotona. Hevosala on merkittävä työllistäjä ja maaseudun elinvoimaisuuden ylläpitäjä tallien ollessa yleensä maaseudulla tai maatilojen yhteydessä.

Hevosalan yritykset ovat nuoria ja ovat investoineet aktiivisesti vuosina 2000-2005. Investointien kokonaisvolyymi jatkuu lähitulevaisuudessa samalla tasolla. Keskimääräisen tallipaikkojen lukumäärän maltillinen kasvu viestii, että yritykset laajentavat toiminta erityisesti tallikapasiteetin käyttöastetta parantamalla. Suuret investoinnit keskittyvät pääkaupunkiseudulle ja suurten kaupunkien ympäristöön. Harrastus- ja yritystallien pääasialliset toimintamuodot säilyvät samankaltaisina, mutta palvelutoiminta, kuten hevosmatkailu- ja elämyspalvelut ovat kasvava osa hevosalan yrittäjyyttä. Mahdollisuuksia on edelleen hevosen käytössä osana terveydenhuolto- ja sosiaalialan palveluita. Monipuolisuudessaan hevosala tarjoaa uusia yritystoiminnan mahdollisuuksia.

Hevosalalle syntyy uusia yrityksiä ja työpaikkoja. Mikäli kyselyyn vastanneiden harrastajien suunnitelmat yritystoiminnan aloittamiseen toteutuvat, syntyy Suomeen vuoteen 2010 mennessä 1300 uutta hevosalan yritystä. Painopiste yritystoiminnan aloittamisessa keskittyy Etelä-Suomeen, jossa uusia yrityksiä syntyy arviolta 500. Työllistävyysvaikutus on merkittävä, sillä hevosala vaikuttaa muihin palvelutoimintoihin, kuten rehu-, varuste- ja tarvikekauppaan, eläinlääkintäpalveluihin ja kengityspalveluin. Hevosalan kasvu tarjoaa myös mahdollisuuksia maatiloille rehuntuotannon kautta.

Kasvu aiheuttaa kehittämistarpeita tiedonsiirtoon ja osaamisen turvaamiseen. Hevosalan kasvu aiheuttaa haasteita erityisesti ympäristökysymyksissä ja hevosen hyvinvoinnin turvaamisessa. Tiedonsiirtoon, yritysosaamiseen ja hevostaitojen ammattiosaamiseen on jatkuvasti panostettava, jotta hevosala säilyy kilpailukykyisenä muiden vapaa-ajanpalvelujen joukossa. Viime kädessä korkealaatuiset palvelut paitsi hyödyttävät hevosyritysten asiakkaita myös edistävät hevosten hyvinvointia. 